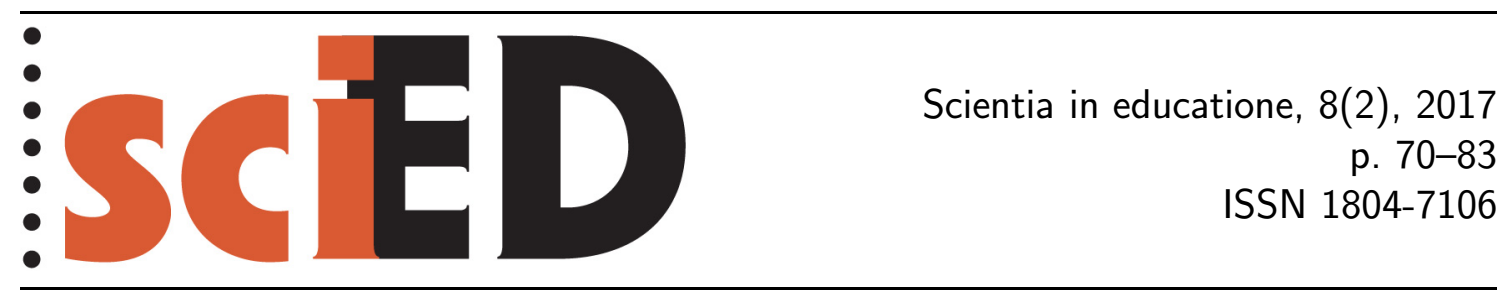

\title{
Predstavy žiakov o vylučovacej a endokrinnej sústave
}

\author{
Milan Kubiatko
}

\begin{abstract}
Abstrakt
Cielom výskumu bolo zistit predstavy žiakov druhého stupňa základných škôl o vylučovacej a endokrinnej sústave. Predvýskumu sa zúčastnilo 78 respondentov a hlavného výskumného šetrenia 204 respondentov. Ako výskumný nástroj slúžil obrys l’udského tela, do ktorého respondenti zakreslovali požadované informácie. Ďalším cielom bolo determinovat vplyv vybraných premenných, ktoré môžu vplývat na úroveň mylných predstáv. Medzi tieto premenné patrili: gender, umiestnenie základnej školy (vidiek vs. mesto), navštevovaný ročník, prítomnost lekára v rodine a vnímanie vlastného zdravia. Na určenie rozdielu medzi skupinami nezávislých premenných bola použitá analýza rozptylu. Pri porovnaní vylučovacej a endokrinnej sústavy boli orgány vylučovacej sústavy zakreslované častejšie. Premenné s významným vplyvom na predstavy žiakov o vylučovacej a endokrinnej sústave boli gender, navštevovaný ročník, umiestnenie školy a vnímanie vlastného zdravia.
\end{abstract}

Klíčová slova: detská kresba, endokrinná sústava, vylučovacia sústava, žiaci druhého stupňa základných škôl.

\section{Pupils' Ideas about Urinary and Endocrine System}

\begin{abstract}
The aim of the study was to survey lower secondary school pupils' understanding of endocrine and urinary system. The pilot study was carried out among 78 respondents and the main research was carried out among 204 respondents. The contour of human body drawn on an A4-size paper was used as a research tool, with the students being asked to fill in the required information. Another aim was to determine the influence of selected variables like gender, school location (village vs. town), year of study, presence of a doctor in the family and the pupil's perception of his or her own health. The analysis of variance was used as statistical method. The pupils tended to add drawings of urinary system organs more frequently than those of the endocrine system. The variables with significant influence on the results were gender, year of study, school location and the pupil's perception of his or her own health.
\end{abstract}

Key words: children's drawing, endocrine system, urinary system, lower secondary school pupils. 
Poznanie l’udského tela by malo patrit medzi základnú vedomostnú bázu každého jednotlivca, pretože bez podstatných informácií o našom tele sa o seba nedokážeme adekvátne postarat a taktiež poskytnutie pomoci inému v prípade nutnosti môže byt problematické. V záujme celej spoločnosti by malo byt, aby dieta už od útleho veku bolo oboznamované s teoretickými znalostłami o l’udskom tele a s postupujúcim vekom by sa na ne mali nabal'ovat’ d’alšie informácie, neskôr aj s praktickými znalostami, ktoré by mali žiakom umožnit’ spoznat fungovanie l’udského tela po anatomickej a fyziologickej stránke. Cielom výskumného šetrenia bolo zistit predstavy žiakov základných škôl o ludskom tele. Výskum prebiehal v dvoch etapách. V prvej mali žiaci nakreslit jednotlivé sústavy ludského tela (táto etapa slúžila ako predvýskum) a druhá etapa sa zamerala na predstavy žiakov o endokrinnej a vylučovacej sústave.

\section{TEORETICKÉ VYMEDZENIE ZÁKLADNÝCH POJMOV}

V rámci prezentovanej štúdie sa pracuje najmä s pojmami predstava a mylná predstava. Predstavy sú obrazy, ktoré napodobujú niečo, čo je nám známe, čo sme predtým niekedy vnímali. Sú to obrazy niečoho, čo je pre nás pomerne nové. V prvom prípade sa jedná o predstavy pamäti, v druhom prípade zas o predstavy fantázie. Deti a umelci majú živšie predstavy v porovnaní s l’ud’mi, ktorí pri práci používajú abstraktné myslenie (Čáp, 1983).

Pojem mylná predstava je chápaný vo význame chybného ponímania skutočnosti, niekedy býva označovaný aj ako miskoncepcia. Tento termín môže byt chápaný ako jedna z podôb ponímania učiva žiakmi, alebo ako súčast̉ chybných žiackych predstáv a nesprávneho ponímania učiva (Schneider \& Ohadi, 1998). V niektorých prácach je možné nájsț náznaky toho, aby sa pojmy miskoncepcia a mylná predstava rozlišovali. Ale napríklad Duit (2002) presadzuje zjednotenie uvedených termínov.

Učitelia majú velké penzum možností pôsobit na predstavy žiakov. Ale ani kvalitný výklad nového učiva učitelom nemusí ovplyvnit predstavy žiakov. Žiak si stále môže stát za svojimi predstavami. Môže sa nechat ovplyvnit len z časti, čast budú tvorit’ nové odborne správne informácie a čast' pôvodné predstavy. To vedie $\mathrm{k}$ celkovému neúplnému porozumeniu a nepochopeniu súvislosti. Táto mylná koncepcia je označovaná ako miskoncepcia alebo mylná predstava. Tieto mylné predstavy spomalujú proces učenia. Pre odhalenie mylných predstáv je potreba špeciálneho diagnostického úsilia (Č́p \& Mareš, 2001). Podobné ponímanie mylných predstáv je možné nájst’ aj v zahraničných prácach (napr.: Bahar, 2003; Fisher, 1985; Nakhleh, 1982).

K odhalovaniu mylných predstáv žiakov o určitej udalosti, situácii a skutočnosti sú používané rozhovory, didaktické otázky, pojmové mapy a taktiež kresby. V rámci prezentovaného výskumného šetrenia je ako výskumný nástroj použitá kresba. Kresba dáva žiakom príležitost, aby vyjadrili svoje myšlienky a odpovede volnejšie v porovnaní s inými výskumnými technikami (Costu et al., 2007). Ako uviedli Prokop a Fančovičová (2006), kresby sú jednoduché nástroje, ktoré slúžia k jednoduchému porovnaniu na medzinárodnej úrovni. Kresba môže byt použitá pri odhalovaní predstáv a poznatkov pri bežnej činnosti

a zbiera velký počet dát. Ako je možné vidiet, kresba poskytuje žiakom príležitost' preukázat svoje vedomosti bez obmedzenia a dáva príležitost' $\mathrm{k}$ porovnaniu výsledkov v rôznych krajinách a medzi rôznymi kultúrami (Bartoszeck, Machado \& Amann-Gainotti, 2008). Žiaci nemusia mat radi odpovedanie na otázky, môžu mat problémy pri vyjadrení myšlienok v písomnej forme. Na druhej strane kresba 
môže byṫ pre žiakov jednoduchá a nezatažujúca činnost'. Kresby odrážajú obraz mysli žiakov a často bývajú používané k výskumným účelom. Kresba bola napríklad použitá k preskúmaniu predstáv žiakov o vybraných abstraktných pojmoch v iných prípadoch mali respondenti vyjadrit ako si predstavujú vnútornú štruktúru l’udského tela a iné (Köse, 2008).

\section{SÚČASNÝ STAV RIEŠENEJ PROBLEMATIKY}

Výskumných prác zameraných na skúmanie mylných predstáv neustále pribúda. Nižšie sú prezentované výskumné štúdie sa týkajú problematiky identifikovania mylných predstáv o l’udskom tele. Niektoré práce sú zamerané priamo na endokrinnú a vylučovaciu sústavu, ale taktiež na celkovú anatómiu ludského tela.

Reiss a kol. (2002) sa zamerali znalosti žiakov o anatómii ludského tela. Výskumnú vzorku tvorilo viac ako 500 žiakov z 11 rôznych krajín (Austrália, Brazília, Dánsko, Ghana, Island, Severné Írsko, Portugalsko, Rusko, Taiwan, Uganda a Venezuela) vo veku 7 až 15 rokov. Ako výskumná technika bola použitá kresba, kde mali žiaci za úlohu nakreslit ich predstavu o tom, čo je vnútri ludského tela. Autori následne determinovali vplyv genderu, veku a krajiny pôvodu na znalosti o anatómii. Najstarší respondenti dosahovali najvyššie skóre takmer vo všetkých krajinách, okrem Taiwanu, kde boli poznatky o anatómii l’udského tela rovnaké ako u najmladších, tak aj u najstarších respondentov. Medzi chlapcami a dievčatami významný rozdiel preukázaný nebol. Rozdiely medzi jednotlivými krajinami je stanovit tažko. Čo sa týka celkového zhodnotenia, tak žiaci najčastejšie kreslili tráviacu, dýchaciu a opornú sústavu. Na druhej strane velmi málo kresieb obsahovalo pohybovú a endokrinnú sústavu. Ak je zameranie na orgány a nie celé orgánové sústavy, tak takmer všetky kresby obsahovali srdce a mnohé z nich obsahovali orgán z tráviacej sústavy, prípadne určitú koste. Makonore a Reiss (2003) sa zamerali na vedomosti o orgánoch jednotlivých sústav, žiaci nemali problém so zakreslením orgánov tráviacej či obehovej sústavy, problémy boli identifikované u vylučovacej sústavy, kde bolo schopných len $30 \%$ žiakov zakreslit niektorý z orgánov vylučovacej sústavy, orgány endokrinnej sústavy sa nevyskytli v kresbe u žiadneho z respondentov. Autori sa zamerali aj na identifikovanie rozdielov medzi chlapcami a dievčatami, kde nedetekovali významný rozdiel medzi skupinami, a s ohladom na vek, tak u vylučovacej sústavy dochádzalo k zlepšeniu skóre s postupujúcim vekom. Podobne Özsevgec (2007) sa zaoberal tým, čo tureckí žiaci vedia o vnútornej štruktúre tela, pričom na odhalenie predstáv použili výskumníci kresbu. Respondenti dostali papier s obrysom tela človeka a za úlohu mali dokreslit orgány a napísat ich funkciu. Najčastejšie žiaci kreslili srdce a plúca bez ohladu na vek. Orgány pohlavnej sústavy sa na kresbách takmer vôbec nevyskytovali. Problém bol so správnym umiestnením orgánov. Napríklad srdce bolo nakreslené takmer v každej, ale umiestnenie bolo vo velkom počte neprávne. U žiakov sa takisto preukázala neznalost̉ funkcie jednotlivých orgánov.

Arnaudin a Mintzes (1985) sa zamerali na obehovú sústavu a znalosti žiakov o nej. Ako výskumnú techniku použili rozhovor. Prostredníctvom uvedenej výskumnej techniky autori zistili viacerí mylné predstavy u žiakov, medzi ktoré patrilo napríklad nesprávne určenie funkcií srdca, či jeho nákres, ked’ ho mnohí žiaci kreslili ako „valentínske“ srdce. Cakici (2005) skúmal u 10 a 11 ročných žiakov ich predstavy o tráviacej sústave prostredníctvom dotazníka a pološtruktúrovaného rozhovoru. Autori konštatovali, že žiaci uvádzali ako funkcie tráviacej sústavy v prevažnej miere rozomletie prijatej potravy a často sa objavovala aj odpoved' rozdelenia 
prijatej potravy na jednotlivé živiny. Čo sa týkalo jednotlivých orgánov, tak žiaci uvádzali žalúdok ako jediný orgán tráviacej sústavy. Žoldošová a Prokop (2007) skúmali predstavy žiakov o prenatálnom vývoji dietata, pritom ako výskumné techniky boli použité kresby a rozhovor. Vnútorné orgány plodu neboli identifikované u žiadneho respondenta, všetci kreslili plod s hlavou a končatinami a polovica nakreslila aj pupočnú šnúru. Prostredie v maternici mali problém popísat takmer všetci žiaci. Podobný výskum realizovali aj Prokop a Fančovičová (2008), pričom autorov zaujímalo ako žiaci stredných škôl vnímali tehotenstvo. Vo výskumnom šetrení bol použitý dotazník. Autori konštatovali problémy žiakov s oplodnením, s určovaním pohlavia dieṫaṫa, taktiež so vzţahom medzi oplodnením a menštruačným cyklom. Bahar a kol. (2008) sa zamerali na skúmanie predstáv študentov vysokých škôl študujúcich biológiu o obehovej sústave. napriek študijnému odboru bolo evidované, že študenti majú mylné predstavy o vnútornej štruktúre srdca a taktiež ho častokrát nesprávne umiestňovali. Problém s umiestnením srdca, ked' nezáležalo na jeho tvare zistili aj Kubiatko a Balatova (2014) u budúcich učitelov biológie. Bajd, Praprotnik a Matyášek (2008) uvádzali podobné výsledky, ako predošlé dve zmieňované štúdie medzi slovinskými a českými študentmi pedagogických fakúlt. Podobne Havu-Nuutinen a Keinonen (2010) zistovali medzi žiakmi fínskych základných škôl ich predstavy o umiestnení jednotlivých orgánov l’udského tela a ich funkcii. Autori identifikovali, že žiaci dokázali nakreslit len niektoré orgány, ale nedokázali uviest’ ich funkciu, prípadne len vo velmi obmedzenej miere. Následne autori aplikovali niekolko týždňový blok vyučovania podla bádatel'sky orientovanej koncepcie. Po jej implementácii výskumníci opätovne zadali kresbu žiakom a po vyhodnotení uviedli oproti predošlej verzie nakreslenie viacerých orgánov, ktoré boli žiaci schopní spájat aj do orgánových sústav a taktiež boli schopní uviest' aj ich funkcie.

\section{Ciele VÝsKumnéHo ŠEtREniA}

Výskumné šetrenie je možné rozdelit na dve základné etapy. V prvej etape bolo hlavným overit výskumný nástroj na skúmanie mylných predstáv u žiakov druhého stupňa základných škôl a l’udskom tele. Ďalším cielom bolo na základe výsledkov predvýskumného šetrenia identifikovat’ orgánové sústavy l’udského tela, s ktorými majú žiaci najväčší problém.

V druhej etape výskumu bolo ciel’om zistit úroveň predstáv žiakov základných škôl o vylučovacej a endokrinnej sústave. Ďalším cielom bolo determinovat vplyv vybraných premenných, ktoré môžu vplývat na úroveň predstáv. Medzi tieto premenné patrili: gender, umiestnenie základnej školy (vidiek vs. mesto), navštevovaný ročník, prítomnost' lekára v rodine a vnímanie vlastného zdravia.

\section{Metodika}

\subsection{RESPONDENTI}

Predvýskumného šetrenia sa zúčastnilo celkom 78 žiakov druhého stupňa základných škôl z Českej republiky, pričom boli zastúpení žiaci zo všetkých ročníkov. Hlavného výskumného šetrenia sa zúčastnilo celkom 204 žiakov druhého stupňa základných škôl. Celkom 87 žiakov bolo zo základnej školy, ktorá bola umiestnená v meste a ostatní $(n=117)$ boli zo základnej školy, ktorá bola umiestnená vo vidieckom 
prostredí. Mesto, v ktorom bola umiestnená škola, malo viac ako 100 tisíc obyvatelov a vidiecka obec, v ktorej bola lokalizovaná škola, mala menej ako 5 tisíc obyvatelov. Výskumu sa zúčastnilo celkom 109 dievčat a 95 chlapcov. Prítomnost̉ lekára v rodine označilo 27 respondentov. S ohladom na navštevovaný ročník, najmladších respondentov bolo 52 , siedmakov 48, z ôsmeho ročníka bolo 56 respondentov a zvyšok $(n=48)$ bolo z deviateho ročníku základnej školy.

\subsection{VÝSKUMNÝ NÁSTROJ}

V rámci predvýskumného šetrenia bola na zistenie úrovne predstáv o l’udskom tele použitá kresba, kde žiaci mali na formát listu A4 do predkresleného obrysu ludského tela nakreslit a popísat’ všetko, čo si myslia, že je v l'udskom tele.

V rámci hlavného výskumného šetrenia bol použitý výskumný nástroj k zisteniu predstáv o endokrinnej a vylučovacej sústave rozdelený do troch častí. Prvá čast’ sa týkala demografických položiek (gender, navštevovaný ročník, prítomnost' lekára v rodine, umiestnenie školy). Druhá čast sa zameriavala na to, ako respondenti vnímali vlastné zdravie. Táto čast' pozostával z 15 položiek Likertovho typu, obsahujúcich 5-bodový odpoved’ový formát. Väčšina otázok bola formulovaná v negatívnom zmysle $(n=9)$ a 6 otázok bolo v pozitívnom význame. Dotazník na vnímanie vlastného zdravia bol prebraný od autorov Wallach a kol. (2001) a adaptovaný na lokálne podmienky. Tretia čast’ výskumného nástroja bola zameraná na znalosti respondentov o vylučovacej a endokrinnej sústave. Ako v predvýskume, tak aj v hlavnom výskume bola použitá analýza detskej kresby. Respondentom bol poskytnutý obrys ludského tela na formáte $\mathrm{A} 4$ a ich úlohou bolo nakreslit' a popísat' vylučovaciu a endokrinnú sústavu. Kresby boli hodnotené na stupnici, vychádzajúc zo štúdie od autorov Prokop, Fančovičová a Tunnicliffe (2009), ktorá vychádzala z hodnotiacej stupnice od autorov Reiss a Tunnicliffe (2001):

Šest’ bodov na stupnici pre vyhodnocovanie vylučovacej sústavy:

Úroveň 1 - žiadne zastúpenie orgánov vylučovacej sústavy

Úroveň 2 - jeden alebo viac orgánov vylučovacej sústavy umiestnených náhodne

Uroveň 3 - jeden orgán vylučovacej sústavy v správnej polohe

Úroveň 4 - dva alebo tri orgány vylučovacej sústavy na správnej pozícii

Úroveň 5 - každý zo štyroch orgánov vylučovacej sústavy (obličky, močovody, močový mechúr a močová trubica) na správnej pozícii, ale žiadny vztah medzi nimi nie je uvedený

Úroveň 6 - každý zo štyroch orgánov vylučovacej sústavy (obličky, močovody, močový mechúr a močová trubica) na správnej pozícii a je medzi nimi zobrazený vztah.

Šst’ bodov stupnice pre vyhodnocovanie endokrinnej sústavy:

Úroveň 1 - žiadne zastúpenie orgánov endokrinnej sústavy

Úroveň 2 - jeden alebo viac orgánov endokrinnej sústavy umiestnených náhodne

Úroveň 3 - jeden orgán endokrinnej sústavy v správnej polohe

Úroveň 4 - dva alebo tri orgány endokrinnej sústavy na správnej pozícii

Úroveň 5 - štyri alebo pät orgánov endokrinnej sústavy na správnej pozícii

Úroveň 6 - každý z ôsmych orgánov endokrinnej sústavy (hypofýza, šuškovité teliesko, štítna žlaza, prištítne telieska, brzlík, nadobličky, podžalúdková žlaza, pohlavné žlazy) na správnej pozícii. 


\subsection{ANALÝZA ZÍSKANÝCH DÁT}

Pri predvýskume bolo zameranie len na určenie sústav, ktoré robili žiakom problém. Najskôr prebehlo zaradenie do jednotlivých úrovní a následne percentuálne vyhodnotenie úspešnosti.

Pri hlavnom výskumnom šetrení bolo najskôr zistené percentuálne zastúpenie jednotlivých úrovní u vylučovacej a endokrinnej sústave a taktiež percentuálne zastúpenie jednotlivých orgánov vyššie zmienených dvoch sústav. Na určenie rozdielu medzi skupinami nezávislých premenných bola použitá analýza rozptylu. Medzi nezávislé premenné patrili gender, navštevovaný ročník, prítomnost' lekára a umiestnenie školy. Závislú premennú predstavovali výsledky detskej kresby. Navštevovaný ročník obsahoval viac ako dve skupiny, preto kvôli detailnému určeniu rozdielov medzi jednotlivými ročníkmi bol použitý Tukeyho post-hoc test. K zisteniu vztahu medzi vnímaním vlastného zdravia a úrovňou znalostí z vylučovacej a endokrinnej sústavy bol použitý Pearsonov korelačný koeficient.

\section{VÝSLEDKY}

\subsection{ZiSTENIA Z PREDVÝSKUMNÉHO ŠETRENIA}

Výsledky týkajúce sa predvýskumu boli rozdelené na dve základné skupiny, a to prítomnost sústav, ale s nesprávnym umiestnením, a prítomnost sústav či orgánov so správnym umiestnením. Napríklad, ak žiak nakreslil srdce ako zástupcu obehovej sústavy, ale nakreslil ho na nesprávnom mieste alebo nezodpovedajúcej velkosti, bola kresba radená do nesprávneho umiestnenia. A ak srdce približne odpovedalo velkosti a bolo správne umiestnené, tak výsledok pripadol ku správnemu umiestneniu. Pri hodnotení prítomnosti orgánov a sústav, ale s ich nesprávnym umiestnením, najčastejšie uvádzali respondenti orgány obehovej sústavy, najčastejšie bolo nakreslené srdce, zriedkavo sa objavovali žily a tepny. Vysoké zastúpenie orgánov mala aj nervová sústava, pričom bol najčastejšie kreslený mozog. Plúca boli najčastejšie kreslené ako orgán dýchacej sústavy. Vysoké zastúpenie mali taktiež orgány tráviacej sústavy, najčastejšie žalúdok, pričom sa v niektorých kresbách objavovali aj tenké a hrubé črevo. Nízke zastúpenie mali orgány vylučovacej sústavy, pohybovej a opornej sústavy. Pohlavná a endokrinná sústava mali velmi nízke zastúpenie.

Pri analýze zastúpenia jednotlivých sústav a ich správneho umiestnenia najvhodnejšie kreslili a umiestňovali orgány nervovej sústavy $(88,46 \%$ ). Takmer dve tretiny respondentov správne umiestňovali orgány dýchacej a obehovej sústavy. Pri ostatných sústavách už nastal u žiakov problém so správnym umiestnením, u žiadnej z nich nedosahovalo správne umiestnenie ani $20 \%$ oslovených žiakov, pričom orgány endokrinnej sústavy sa nevyskytovali vôbec v žiadnej analyzovanej kresbe.

\subsection{ZiSTENIA Z HLAVNÉHO VÝSKUMU}

Pri porovnaní predstáv žiakov o vylučovacej a endokrinnej sústave je možné povedat', že respondenti mali horšie povedomie o endokrinnej sústave v porovnaní s vylučovacou sústavou. Ako je možné vidiet $\mathrm{v}$ grafe 1 , tak úroveň 1 bola u endokrinnej sústavy na hodnote takmer $80 \%$, čo znamená žiadne zastúpenie orgánov endokrinnej sústavy, pričom nezastúpenie orgánov vylučovacej sústavy bolo detekované len u približne $25 \%$ respondentov. V dalších úrovniach, kde už respondenti kreslili orgány vylučovacej a endokrinnej sústavy bolo vyššie skóre identifikované práve u vylučovacej sústavy. Úrovne 5 a 6 zastúpenie nemali. 


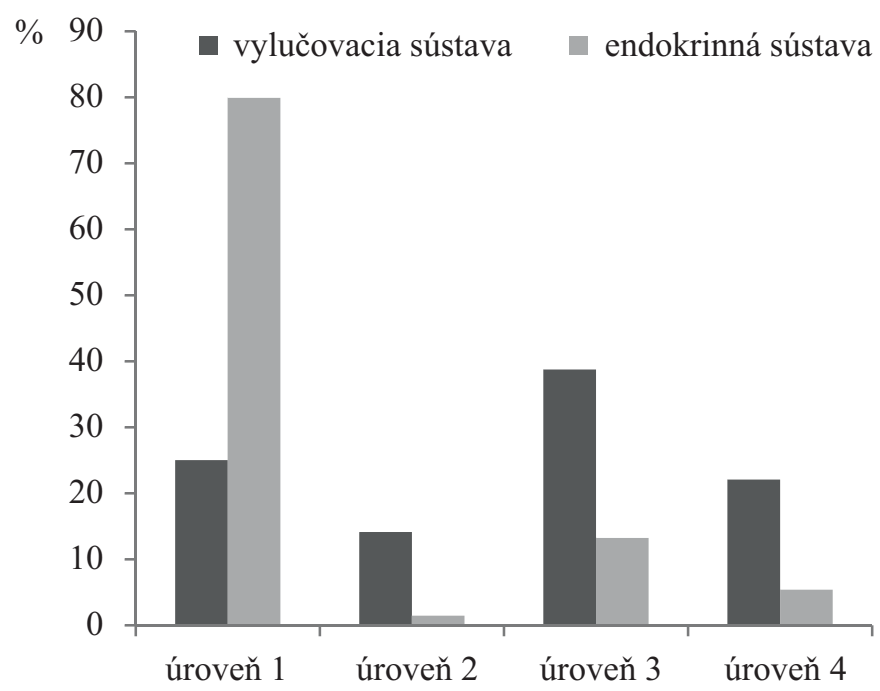

Graf 1: Percentuálne zastúpenie jednotlivých úrovní u endokrinnej a vylučovacej sústavy

V tabulke 1 je uvedená prítomnoste jednotlivých orgánov vylučovacej sústavy. Najčastejšie boli uvedené močový mechúr a obličky, ale pri ich správnom umiestnení už boli evidované rozdiely. Obličky boli zo všetkých nákresov správne umiestnené vo viac ako polovici prípadov, pričom močový mechúr bol správne umiestnený z prípadov, kde bol uvedený takmer vždy. Močovú rúru nakreslilo len o málo viac ako $10 \%$ respondentov, ale takmer všetci respondenti, ktorí ju nakreslili, ju aj správne umiestnili. Najnižšie zastúpenie mali močovody, ale ked’ boli uvedené, tak boli správne nakreslené vo všetkých prípadoch.

Tab. 1: Percentuálne vyhodnotenie prítomnosti jednotlivých orgánov vylučovacej sústavy a ich správne resp. nesprávne umiestnenie

\begin{tabular}{lccc}
\hline Orgán & $\begin{array}{c}\text { Prítomnost } \\
{[\%]}\end{array}$ & $\begin{array}{c}\text { Správne } \\
\text { umiestnenie [\%] }\end{array}$ & $\begin{array}{c}\text { Nesprávne } \\
\text { umiestnenie [\%] }\end{array}$ \\
\hline obličky & 57,35 & 57,26 & 42,73 \\
\hline močovody & 6,37 & 100,00 & 0,00 \\
\hline močový mechúr & 57,84 & 94,92 & 5,08 \\
\hline močová rúra & 10,78 & 90,91 & 9,09 \\
\hline
\end{tabular}

V tabul'ke 2 je uvedená prítomnost' jednotlivých orgánov endokrinnej sústavy a ich správne resp. nesprávne umiestnenie. Pohlavné žlazy boli rozdelené na mužské a ženské. Najčastejšie z orgánov endokrinnej sústavy bola zobrazovaná štítna žlaza, nakreslilo je takmer 10 \% respondentov. O niečo menej boli uvádzané respondentmi semenníky, potom nasledovali nadobličky, ktoré boli nakreslené viac ako $5 \%$ respondentov. Ostatné orgány endokrinnej sústavy boli identifikované v menej ako $5 \%$ prípadov. Ak boli orgány zobrazené, tak takmer vo všetkých prípadoch boli aj správne umiestnené, akurát štítna žlaza, brzlík a podžalúdková žlaza neboli vždy správne umiestnené.

Okrem orgánov, ktoré patria k vylučovacej a endokrinnej sústave, respondenti uvádzali aj orgány, ktoré prináležia k iným sústavám. Najčastejšie boli zobrazené črevá, takmer v polovici analyzovaných kresbách sa tieto orgány vyskytli, pričom žiaci uviedli, že patria k vylučovacej sústave. Podobne k vylučovacej sústave zaradila takmer štvrtina respondentov žalúdok a konečník. Takmer $15 \%$ respondentov uviedlo mozog ako súčast endokrinnej sústavy. Potom ešte v menej ako $5 \%$ boli uvádzané plúca, hltan či pažerák ako orgány vylučovacej resp. endokrinnej sústavy. 
Tab. 2: Percentuálne vyhodnotenie prítomnosti jednotlivých orgánov endokrinnej sústavy a ich správne resp. nesprávne umiestnenie

\begin{tabular}{lccc}
\hline Orgán & $\begin{array}{c}\text { Prítomnost } \\
{[\%]}\end{array}$ & $\begin{array}{c}\text { Správne } \\
\text { umiestnenie [\%] }\end{array}$ & $\begin{array}{c}\text { Nesprávne } \\
\text { umiestnenie [\%] }\end{array}$ \\
\hline hypofýza & 2,94 & 100,00 & 0,00 \\
\hline šuškovité teliesko & 0,98 & 100,00 & 0,00 \\
\hline štítna žlaza & 9,31 & 94,73 & 5,27 \\
\hline prištítne telieska & 1,96 & 100,00 & 0,00 \\
\hline brzlík & 3,92 & 50,00 & 50,00 \\
\hline nadobličky & 5,39 & 100,00 & 0,00 \\
\hline podžalúdková žlaza & 4,41 & 77,78 & 22,22 \\
\hline vaječníky & 3,92 & 100,00 & 0,00 \\
\hline semenníky & 8,82 & 100,00 & 0,00 \\
\hline
\end{tabular}

Ďalej boli prostredníctvom induktívnej štatistiky zistoované rozdiely medzi skupinami premenných a vztahy medzi premennými. Výsledky s ohladom ne gender ukázali významný rozdiel medzi chlapcami a dievčatami pri vylučovacej sústave $(F=4,54 ; p<0,05)$, pričom dievčatá dosahovali vyššie skóre $(x=2,89 ; S E=0,12)$ v porovnaní s chlapcami $(x=2,52 ; S E=0,13)$. Pri endokrinnej sústave nebol identifikovaný významný rozdiel $(F=2,02 ; p=0,16)$, s tým, že u dievčat bolo detekované vyššie skóre $(x=1,58 ; S E=0,10)$ v porovnaní s chlapcami $(x=1,38$; $S E=0,10)$. Pri hodnotení navštevovaného ročníku nebol pri vylučovacej sústave zistený významný rozdiel $(F=0,84 ; p=0,47)$, pričom najnižšie skóre dosiahli žiaci šiesteho ročníka $(x=2,50 ; S E=0,18)$ a najvyššie bolo zistené u žiakov ôsmeho ročníka $(x=2,86 ; S E=0,17)$. U endokrinnej sústavy bol identifikovaný významný rozdiel s ohladom na navštevovaný ročník $(F=5,20 ; p<0,01)$. Tukeyho post-hoc test poukázal na to, že žiaci šiesteho ročníka dosahovali významne nižšie skóre v porovnaní so žiakmi siedmeho a aj so žiakmi deviateho ročníku na úrovni $p<0,05$. Najnižšie skóre dosiahli žiaci šiesteho ročníka $(x=1,12 ; S E=0,13)$ a najvyššie žiaci siedmeho ročníka $(x=1,79 ; S E=0,14)$. Distribúcia skóre u endokrinnej sústavy s ohladom na jednotlivé ročníky je zobrazená v grafe 2 .

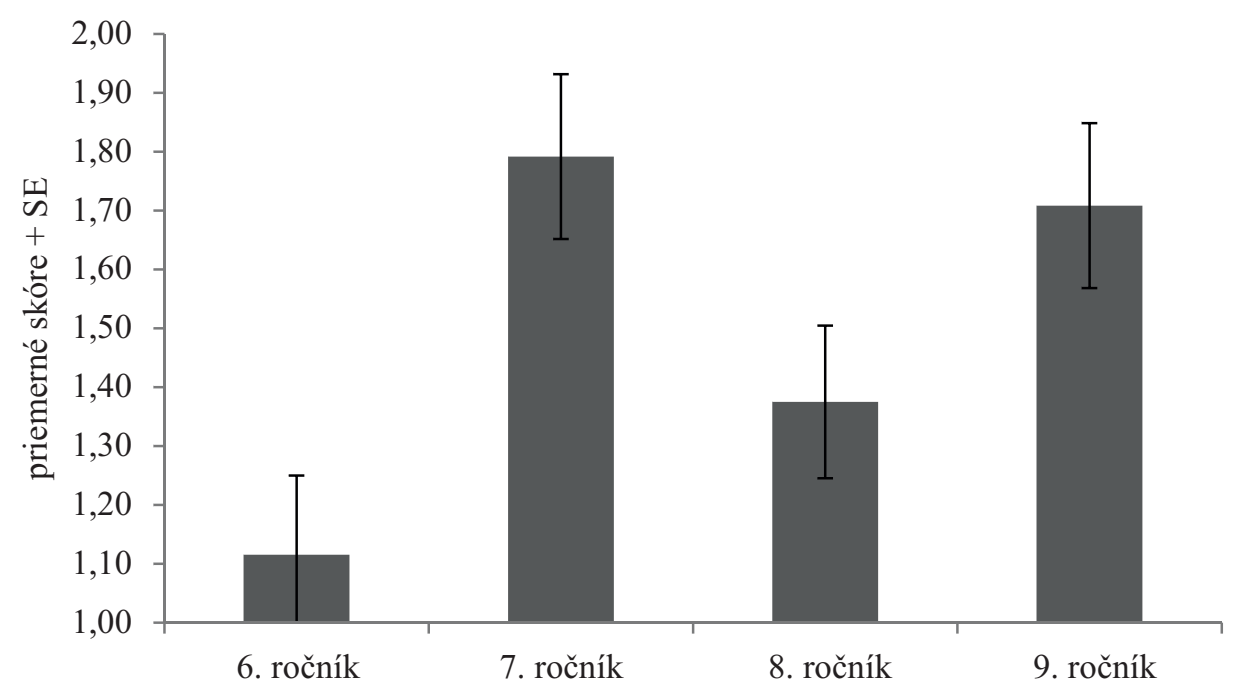

Graf 2: Distribúcia skóre u endokrinnej sústavy s ohladom na navštevovaný ročník 
Prítomnost' lekára v rodine sa nepreukázal ako významný faktor. V prípade vylučovacej sústavy bola hodnota analýzy rozptylu $F=2,34(p=0,13)$ a v prípade endokrinnej sústavy $F=0,95(p=0,55)$. U endokrinnej sústavy dosahovali vyššie skóre respondenti, ktorí označili prítomnost́ lekára v rodine $(x=1,59 ; S E=0,19)$ v porovnaní s tými, ktorí prítomnoste lekára v rodine nepotvrdili $(x=1,47 ; S E=0,07)$. Pri vylučovacej sústave nastal opačný efekt, tí ktorí nemali lekára v rodine dosahovali vyššie skóre $(x=2,76 ; S E=0,09)$ v porovnaní s respondentmi, ktorí lekára v rodine mali $(x=2,37 ; S E=0,24)$.

Pri hodnotení výsledkov vedomostí z endokrinnej a vylučovacej sústavy s ohladom na umiestnenie školy $\mathrm{v}$ oboch prípadoch dosahovali vyššie skóre respondenti z vidieckeho prostredia. V oboch prípadoch bol evidovaný významný rozdiel vo výsledkoch u vylučovacej sústavy $(F=26,50 ; p<0,001)$ a u endokrinnej sústavy $(F=21,51 ; p<0,001)$. Distribúcia skóre za obe orgánové sústavy s ohladom na umiestnenie školy je zobrazené v grafe 3 .

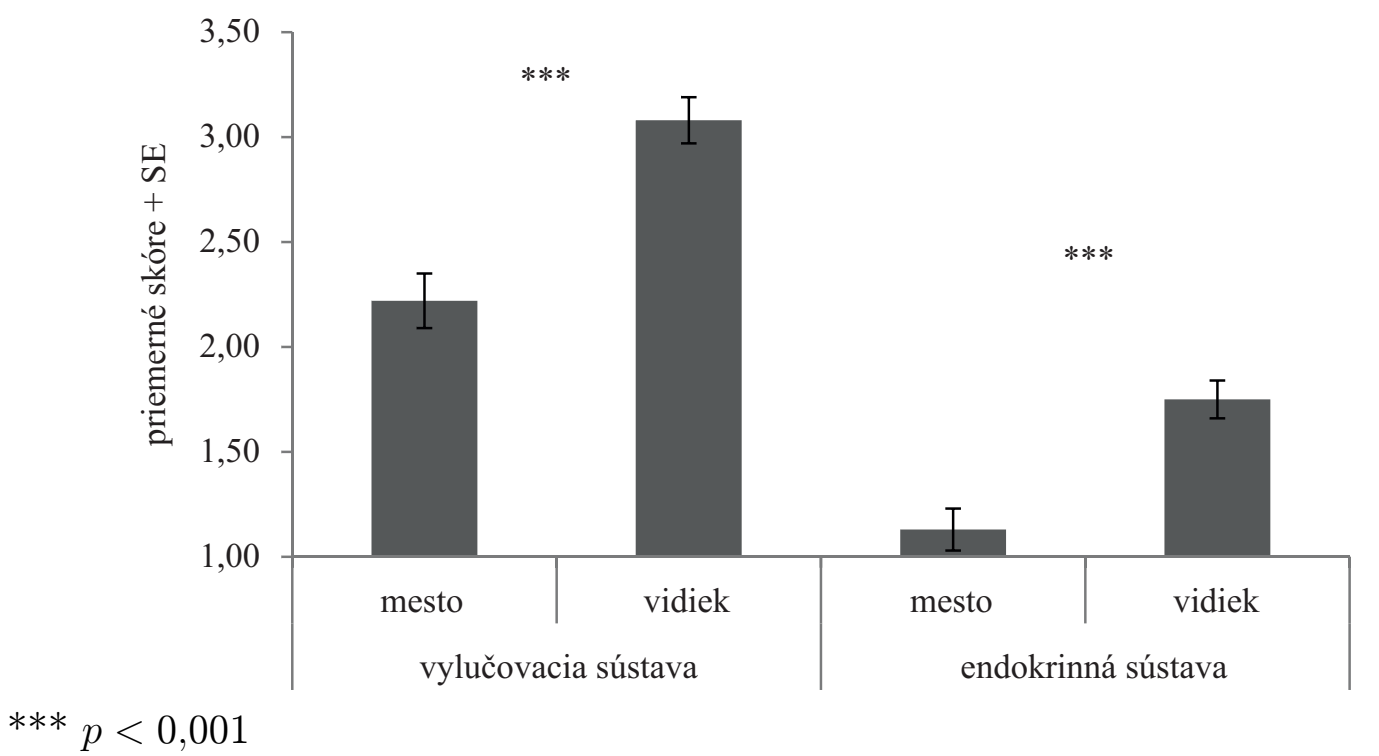

Graf 3: Distribúcia skóre za vylučovaciu a endokrinnú sústavu s ohladom na umiestnenie školy

Poslednou analýzou bolo určenie vztahu medzi vnímaním vlastného zdravia a vedomostami z vylučovacej a endokrinnej sústavy. Vzṫah medzi predstavami o vylučovacej sústave a vnímaním vlastného zdravia bol nevýznamný $(r=-0,02 ; p=0,82)$, ale vztah medzi predstavami o endokrinnej sústave a vnímaním vlastného zdravia bol významný a slabo negatívny $(r=-0,14 ; p<0,05$ (graf 4$)$ ).

\section{Diskusia}

V prvej etape výskumného šetrenia bolo zámerom určit, ktoré sústavy robia žiakom druhého stupňa základných škôl najväčší problém pri ich zakreslovaní do predloženého obrysu l’udského tela. Pri determinovaní najproblémovejších orgánových sústav bolo použité len percentuálne zastúpenie jednotlivých orgánov. Na základe výsledkov boli určené vylučovacia a endokrinná sústava ako tie, ktoré žiakom robili najväčšie problémy, preto v hlavnom výskumnom šetrení bolo zameranie na uvedené dve sústavy a vplyv vybraných premenných na ne. 


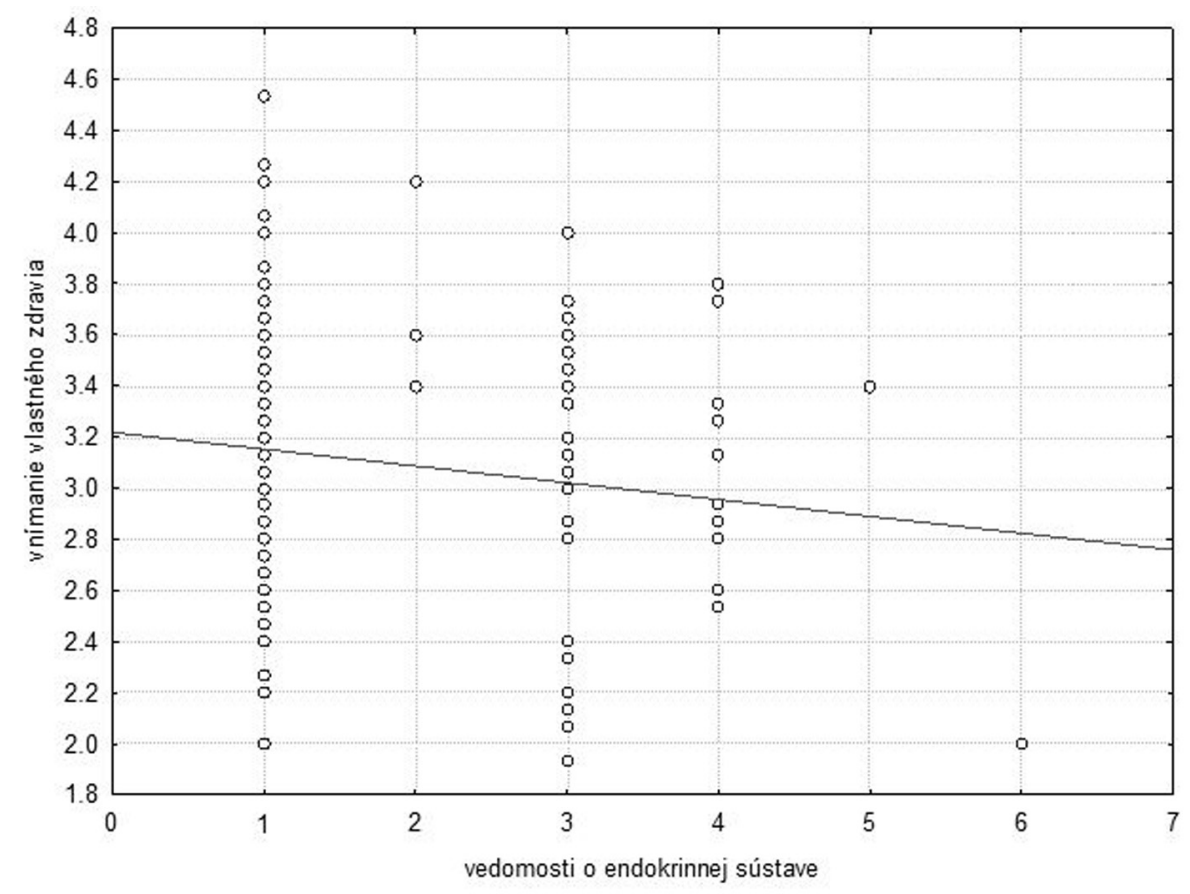

Graf 4: Vztah medzi vnímaním vlastného zdravia a predstavami o endokrinnej sústave

Prvou premennou bol gender, čiže bolo snahou určit rozdiel medzi dievčatami a chlapcami z vedomostí o vylučovacej a endokrinnej sústave. Na základe výsledkov je možné povedate, dievčatá dosahovali vyššie skóre v oboch sústavách v porovnaní s chlapcami. Podobné výsledky, ale o iných sústavách bolo možné nájst aj v prácach d’alších autorov. Napríklad Bahar a kol. (2008) dosahovali lepšie vedomosti pri zakreslovaní srdca a mozgu do predloženého obrysu l’udského tela. Makonore a Reiss (2003) vo výskume realizovanom na žiakoch základných škôl nezistili rozdiel pri zakreslovaní orgánov jednotlivých sústav s ohladom na gender. Kým orgány vylučovacej sústavy bolo možné nájsţ približne u tretiny chlapcov a dievčat, tak orgány endokrinnej sústavy sa nevyskytovali ani v kresbách chlapcov ani v kresbách dievčat. Okrem iných boli predmetom výskumu aj vylučovacia s endokrinnou sústavou. Podobne aj pri zakreslovaní orgánov týkajúcich sa orgánov vylučovacej, dýchacej a tráviacej sústavy dosahovali vyššie skóre dievčatá v porovnaní s chlapcami (Prokop, Fančovičová \& Tunnicliffe, 2009). Lepšie výsledky v kresbe orgánov endokrinnej a vylučovacej sústavy u dievčat je možné pripísat tomu, že dievčatá sa snažia a o ucelenejšie a presnejšie kresby v porovnaní s chlapcami. Tento efekt bol potvrdený napríklad v štúdii od autorov Gabriels a kol. (2000). Podobne Tuman (1999) uviedol vo svojej práci, že pri analyzovaní detských kresieb boli u dievčat pozorované určité charakteristiky, ktoré sa u chlapcov nevyskytovali. Dievčatá boli vo svojich kresbách presnejšie, použivali viac farieb, kresby boli ovela viac detailnejšie ako kresby chlapcov.

Ďalšou premennou, ktorá bola zaradená do výskumného šetrenia, bol navštevovaný ročník. U vylučovacej sústavy boli zistené konzistentné výsledky, najmladší respondenti dosahovali najhoršie výsledky, týkajúce sa predstáv o uvedenej sústave. Narastajúcim vekom stúpal počet správne umiestnených zakreslených orgánov spadajúcich do vylučovacej sústavy. Podobné výsledky uvádza aj Reiss a kol. (2002), ktorí vo svojej práci uviedli lepšie vedomosti starších žiakov o anatómii ludského tela v porovnaní s mladšími respondentmi. Precíznost', úplnost' a presnost kresby s ohladom na vek respondentov boli skúmané aj autorom van Mier (2006), ktorý 
na základe výsledkov uviedol, že s postupujúcim vekom respondentov stúpala presnost', úplnost' a precíznost' kresby. Makonore a Reiss (2003) skúmali vplyv veku na schopnosť žiakov základných škôl zakreslovat orgány rôznych sústav ludského tela. Okrem iných vyhodnocovali aj vylučovaciu a endokrinnú sústavu. Kým pri vylučovacej sústave nastalo s postupujúcim vekom zlepšenie pri zakreslovaní orgánov, tak pri endokrinnej sústave ostal výsledok na rovnakej úrovni. Ako mladší, tak aj starší respondenti nezakreslili ani jeden orgán endokrinnej sústavy. Pri endokrinnej sústave boli identifikované odlišné výsledky, najlepšie výsledky dosiahli žiaci siedmeho ročníka a najhoršie výsledky najmladší respondenti (žiaci šiesteho ročníka). Toto zistenie je relatívne prekvapujúce, pretože sa očakávalo, že práve najstarší respondenti dosiahnu najlepšie výsledky, kedže mali prebrané učivo z anatómie človeka. Výsledok siedmakov je možné vysvetlit tým, že predstavy o endokrinnej sústave majú z anatómie živočíchov.

Prítomnost̉ lekára v rodine sa ukázala ako nevýznamná premenná, kedže ani pri endokrinnej ani pri vylučovacej sústave nebol zistený významný vplyv tejto premennej. Uvedená premenná patrí len medzi okrajovo skúmané. V dostupných databázach nebola nájdená žiadna výskumná práca, ktorá by odkazovala na vplyv uvedenej premennej. Aj ked' rozdiel nebol významný, tak pri endokrinnej sústave dosahovali vyššie skóre respondenti, ktorí označili prítomnost' lekára v rodine, ale pri vylučovacej sústave bol efekt opačný, tam dosahovali vyššie skóre respondenti, ktorí lekára v rodine nemali. Tento jav bol možno spôsobený tým, že choroby súvisiace s endokrinnou sústavou patria medzi častejšie spomínané a bežnejšie, niektoré z nich patria aj medzi tzv. civilizačné choroby (napr. cukrovka). Prípadne choroby endokrinného systému spôsobujú následne ochorenia vylučovacej sústavy. Taktiež je možné nájst' aj informácie o strese ako faktore, ktorý spôsobuje ochorenia endokrinnej sústavy (napr. McEwen \& Stellar, 1993). Preto je možné v rodine, kde je prítomní lekár, počut viac o chorobách endokrinného systému v porovnaní s vylučovacím.

Ďalšou premennou bolo prostredie, kde je umiestnená škola. Pri oboch sústavách, ako vylučovacej, tak aj endokrinnej, dosahovali významne vyššie skóre žiaci $\mathrm{z}$ vidieckeho prostredia. Vplyv rezidencie v oblasti vedomosti o l'udskom tele nebol v dostupných databázach dohladatelný, ale napríklad v oblasti environmentalistiky bol robený výskum na vedomosti a proenvironmentálne správanie (napr. Berenguer, Corraliza \& Martin, 2005) či v prácach týkajúcich sa zoológie (napr. Kellert \& Westervelt, 1984). Väčšina výskumných štúdií, kde bol skúmaný vplyv vidieckeho a mestského prostredia na vedomosti, deklarovali lepšie vedomosti o skúmaných témach u žiakov, ktorí navštevovali školu vo vidieckom prostredí, resp. pochádzali z vidieckeho prostredia. Jednou z možností, ako je možné vysvetlit lepšie skóre u žiakov z vidieckych škôl, je nižší počet žiakov v triedach z mimomestského prostredia (napr. Kučerová et al., 2011), preto má učitel' možnost’ sa venovat’ viac žiakom, individuálne vyučovanie prebieha častejšie ako v mestskom prostredí. Tým dochádza $\mathrm{u}$ žiakov k porozumeniu uvedenej problematiky a nielen $\mathrm{k}$ jej povrchnému osvojeniu.

Poslednou premennou bolo vnímanie vlastného zdravia a jeho vztah s vedomostami o endokrinnej a vylučovacej sústave. Bolo zistené, že žiaci, ktorí vnímali svoj zdravotný stav horšie, dosahovali vyššie skóre v oboch sústavách v porovnaní s respondentmi, ktorí vnímali zdravotný stav lepšie. K tomuto javu mohlo dôjsté pravdepodobne na základe toho, že respondenti, ktorí majú problémy so zdravím, sa viac zaujímajú o stavbu ludského tela a jeho fungovanie, preto boli u nich predstavy na vyššej úrovni. 


\section{ZÁver}

Na základe výsledkov výskumného šetrenia bolo zistených niekolko problematických oblastí v predstavách o endokrinnej a vylučovacej sústave u žiakov druhého stupňa základných škôl. Medzi najčastejšie mylné predstavy patrilo zaradenie orgánov tráviacej sústavy (najmä črevá) medzi orgány vylučovacej sústavy. Potom boli identifikované mylné predstavy o polohe obličiek, prípadne dochádzalo k zámene močovej rúry a močovodov. Pri endokrinnej sústave dochádzalo k určeniu mozgu ako orgánu patriaceho do endokrinnej sústavy. Na úroveň predstáv o oboch sústavách pôsobili premenné ako gender, navštevovaný ročník či umiestnenie školy, ale taktiež aj vnímanie vlastného zdravia.

Výsledky prezentované na základe analýzy dát môžu byṫ užitočné aj pre učitelov, $\mathrm{k}$ výberu vhodných vyučovacích metód a postupov, ktorými by priblížili žiakom orgány vylučovacej a endokrinnej sústavy tak, aby nedochádzalo k zámene s inými sústavami. Vyučovacie metódy by mohli byt’ zamerané na využitie takých didaktických pomôcok a techník, ktoré by žiakom zobrazili v správnej polohe umiestnenie orgánov jednotlivých sústav. Taktiež samotný výskumný nástroj (obrys ludského tela a vyhodnocovacie kódovanie) by mohol byt nápomocný pre učitelov pred začatím preberania anatómie ludského tela tak, aby zistili, aké predstavy majú žiaci o usporiadaní orgánov jednotlivých sústav, ktorá je pre žiakov najproblematickejšia a aké problémy pri jednotlivých sústavách sa zamerate.

\section{LITERATURA}

Arnaudin, M. W. \& Mintzes, J. J. (1985). Students' alternative conceptions of the human circulatory system: A cross-age study. Science Education, 69(5), 721-733.

Bahar, M. (2003). Misconceptions in biology education and conceptual change strategies. Educational Sciences: Theory $\&$ Practice, 3(1), 55-64.

Bahar, M., Ozel, M., Prokop, P. \& Usak, M. (2008). Science student teachers' ideas of the heart. Journal of Baltic Science Education, 7(2), 78-85.

Bajd, B., Praprotnik, L. \& Matyášek, J. (2008). Basic knowledge of the cardiovascular system: A comparison betweenstudents of the faculties of education in Ljubljana (Slovenia) and Brno (Czech Republic). School and Health, 21(3), 7-15.

Bartoszeck, A. B., Machaldo, D.Z. \& Amann-Gainotti, M. (2008). Representations of internal body image: A study of preadolescents and adolescent students in Araucaria, Parana, Brazil. Ciencias \& Cognicao, 13(2), 139-159.

Berengeur, J., Corraliza, J. A. \& Martin, R. (2005). Rural-urban differences in environmental concern, attitudes and actions. European Journal of Psychological Assessment, 21(2), 128-138.

Cakici, Y. (2005). Exploring Turkish upper primary level pupils' understanding of digestion. International Journal of Science Education, 27(1), 79-100.

Costu, B., Ayas, A., Niaz, M., Unal, S. \& Calik, M. (2007). Facilitating conceptual change in students' understanding of boiling concept. Journal of Science Education and Technology, 16(6), 524-536.

Čáp, J. (1983). Psychologie pro učitele. Praha: Státní pedagogické nakladatelství.

Čáp, J. \& Mareš, J. (2001). Psychologie pro učitele. Praha: Portál. 
Duit, R. (2002, June). Conceptual change - still a powerful frame for improving science teaching and learning? Paper presented at the Third European Symposium on Conceptual Change: A Process Approach to Conceptual Change, Turku, Finland.

Fisher, K. M. (1985). A misconception in biology: Amino acids and translation. Journal of Research in Science Teaching, 22(1), 53-62.

Gabriels, R. L., Wamboldt, M.Z., McCormick, D. R., Adams, T. L. \& McTaggart, S.R. (2000). Childrens illness drawings and asthma symptom awareness. Journal of Asthma, $37(7), 565-574$.

Havu-Nuutinen, S. \& Keinonen, T. (2010). The changes in pupils' conceptions of human body based on science, technology and society based teaching. Journal of Baltic Science Education, 9(3), 212-223.

Kellert, S. R. \& Westervelt, M. O. (1984). Children's attitudes, knowledge and behaviors towards animals. Children's Environments Quarterly, 1(3), 8-11.

Köse, S. (2008). Diagnosing student misconceptions: using drawings as a research method. World Applied Sciences Journal, 3(2), 283-293.

Kubiatko, M. \& Balátová, K. (2014). Are storks homosexuals? Persistence of misconceptions among university students. Journal of Baltic Science Education, 13(4), $448-457$.

Kučerová, S., Mattern, T., Štych, P. \& Kučera, Z. (2011). Změny dostupnosti základních škol v Česku jako faktor znevýhodnění regionů a lokalit. Geografie, 116(3), 300-316.

Makonore, V. \& Reiss, M. J. (2003). Pupils drawings of what is inside themselves: A case study in Zimbabwe. Zimbabwe Journal of Educational Research, 15(1), 28-43.

McEwen, B. S. \& Stellar, E. (1993). Stress and the individual mechanisms leading to disease. Archives of Internal Medicine, 153(18), 2093-2101.

Mier van, H. (2006). Developmental differences in drawing performance of the dominant and non-dominant hand in right-handed boys and girls. Human Movement Science, $25(4-5), 657-677$.

Nakhleh, M. B. (1992). Why some students don't learn chemistry - Chemical misconceptions. Journal of Chemical Education, 69(3), 191-196.

Özsevgec, L. C. (2007). What do Turkish students at different ages know about their internal body parts both visually and verbally? Journal of Turkish Science Education, $4(2), 31-44$.

Prokop, P. \& Fančovičová, J. (2006). Students' ideas about the human body: Do they really draw what they know? Journal of Baltic Science Education, 2(10), 86-95.

Prokop, P. \& Fančovičová, J. (2008). Students' understanding of human pregnancy. Journal of Baltic Science Education, 7(1), 37-47.

Prokop, P., Fančovičová, J. \& Tunnicliffe, S. D. (2009). The effect of type of instruction on expression of children's knowledge: How do children see the endocrine and urinary system? International Journal of Environmental \& Science Education, 4(1), 75-93.

Reiss, M. J. \& Tunnicliffe, S. D. (2001). Students' understandings of human organs and organ systems. Research in Science Education, 31(3), 383-399.

Reiss, M. J. a kol. (2002). An international study of young peoples' drawings of what is inside themselves. Journal of Biological Education, 36(2), 58-64. 
Schneider, I. \& Ohadi, M. M. (1998). Unraveling students' misconceptions about the Earth's shape and gravity. Science Education, 82(2), 265-284.

Tuman, D. M. (1999). Gender style as form and content: An examination of gender stereotypes in the subject preference of children's drawing. Studies in Art Education, $41(1), 40-60$.

Wallach, P. M. a kol. (2001). Standardized patients' perceptions about their own health care. Teaching and Learning in Medicine, 13(4), 227-231.

Žoldošová, K. \& Prokop, P. (2007). Primary pupils' preconceptions about child prenatal development. Eurasia Journal of Mathematics, Science \& Technology Education, 3(3), 239-246.

Milan KubiaTKo, mkubiatko@gmail.com

Fakulta humanitných vied ŽU

Katedra pedagogických štúdií

Univerzitná 1, 01026 Žilina, Slovenská republika 